\title{
Can Government Demand Stimulate Private Investment? Evidence from U.S. Federal Procurement
}




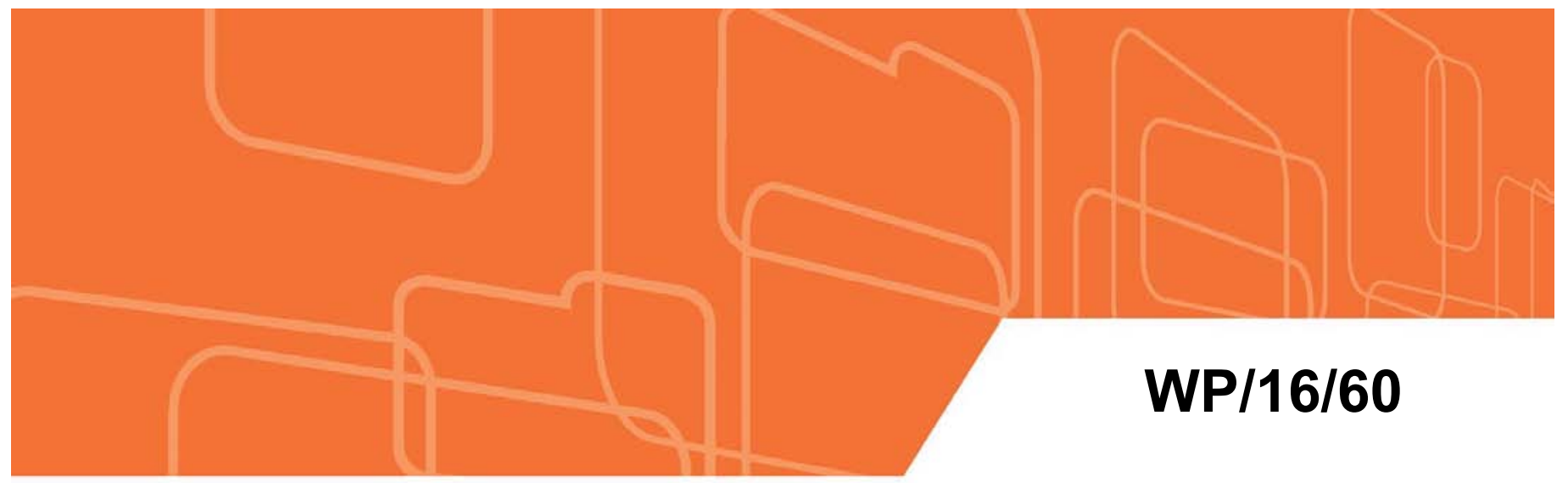

\section{IMF Working Paper}

Can Government Demand Stimulate Private Investment? Evidence from U.S. Federal Procurement

by Shafik Hebous and Tom Zimmermann

I N TER N A T I O A L MONETARY FU N D 


\title{
IMF Working Paper
}

Fiscal Affairs Department

\section{Can Government Demand Stimulate Private Investment? Evidence from U.S. Federal Procurement ${ }^{1}$}

\section{Shafik Hebous and Tom Zimmerman ${ }^{2}$}

Authorized for distribution by Michael Keen

March 2016

IMF Working Papers describe research in progress by the author(s) and are published to elicit comments and to encourage debate. The views expressed in IMF Working Papers are those of the author(s) and do not necessarily represent the views of the IMF, its Executive Board, or IMF management.

\begin{abstract}
We study the effects of federal purchases on firms' investment using a novel panel dataset that combines federal procurement contracts in the United States with key financial firm-level information. We find that 1 dollar of federal spending increases firms' capital investment by 7 to 11 cents. The average effect masks heterogeneity: Effects are stronger for firms that face financing constraints and they are close to 0 for unconstrained firms. In line with the financial accelerator model, our findings indicate that the effect of government purchases works through easing firms' access to external borrowing. Furthermore, industry-level analysis suggests that that the increase in investment at the firm level translates into an industry-wide effect without crowding-out capital investment of other firms in the same industry.
\end{abstract}

JEL Classification Numbers: [E62, H30, E69]

Keywords: Investment, Federal Procurement, Financing Constraints, Spending Multipliers.

Authors' E-Mail Addresses: Shebous@imf.org; tom.zimmermann@frb.gov

\footnotetext{
${ }^{1}$ We received helpful comments from Bob Chirinko, Ruud de Mooij, Yuriy Gorodnichenko, and seminar and conferences participants at the European Central Bank in Frankfurt, IIPF meeting at the University College Dublin, Christmas meeting of German Economists Abroad in Munich, and the SEA meeting in New Orleans. The views expressed here are those of the authors and do not necessarily represent the views of the IMF, its Executive Board, IMF management, or the Federal Reserve Board of Governors.

${ }^{2}$ Shafik Hebous, International Monetary Fund and Goethe University Frankfurt shebous@imf.org, Tom Zimmermann, Federal Reserve Board, tom.zimmermann@frb.gov
} 


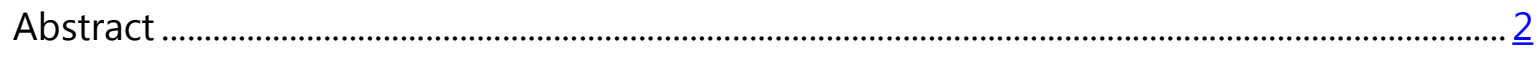

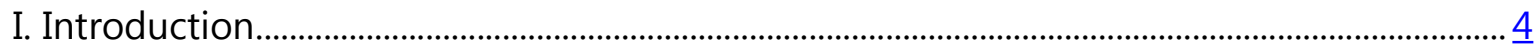

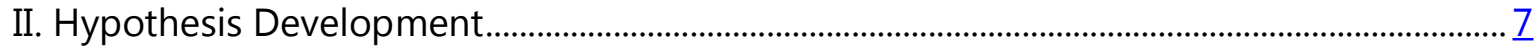

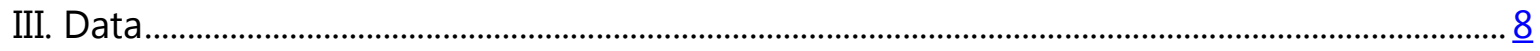

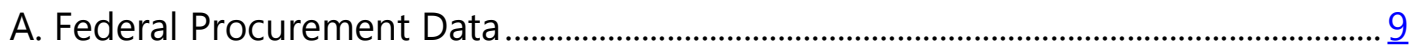

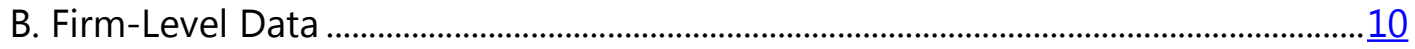

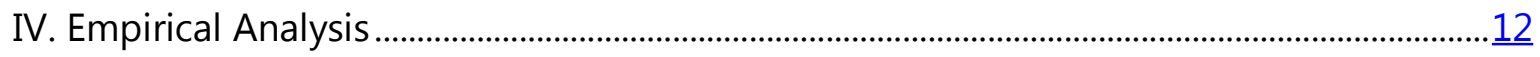

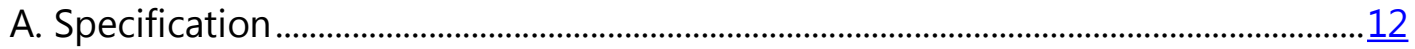

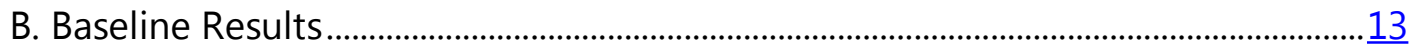

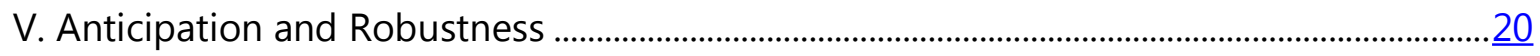

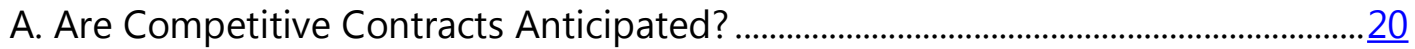

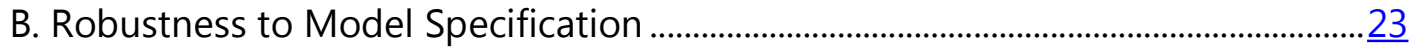

C. Robustness to Contract Selection ............................................................................... 23

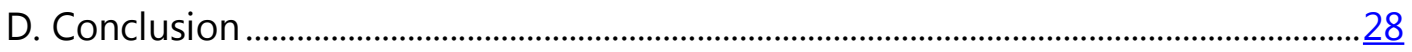

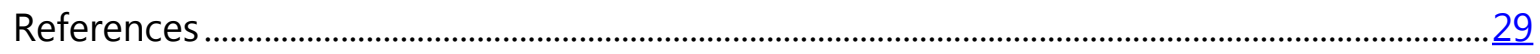




\section{INTRODUCTION}

A key question in macroeconomics and finance is whether government demand stimulates private investment. In this paper, we address this question by examining the effects of government spending on firms' capital investment using novel micro-level data on federal procurements in the United States.

We argue that the response of capital investment of financially constrained firms to government demand shocks is more pronounced than that of non-constrained firms. Our argument can be motivated by the financial accelerator framework of Bernanke et al. (1996). Without financial frictions, optimal capital investment is determined by equating the marginal product of capital and the real price of capital. However, consider a firm that cannot reach this optimum due to financing constraints, thus requiring external funding to invest in inputs of its production function. Because the collateral-in-advance constraint is binding, a financing premium hinders firms' external borrowing. Within this minimal setup, the creation of new government demand increases the net wealth of the firm through the additionally generated cash flow. The new government demand reduces the external financing premium, thereby relaxing the constraint and hence increasing firms' demand for inputs. The hypothesis that follows from this simple model is that government demand shocks increase capital investment particularly for financially constrained firms.

To test this hypothesis, we link data from two different sources. The Federal Funding Accountability and Transparency Act (FFATA), signed in September of 2006, requires the Office of Management and Budget $(\mathrm{OMB})$ to organize a database including each contract transaction awarded by federal agencies in the United States from 2000 onwards. Key information includes the name of the contractor, the value, and the date of the award. According to the $\mathrm{OMB}$, the aggregate annual value of awarded federal contracts in the United States has been close to 500 billion dollars in the last years. We merge the data on federal contracts with information on the contractors, such as capital expenditure, total assets, and other financial variables obtained from Compustat. The resulting dataset is novel and includes about 94,000 quarterly observations from 2000Q1 to 2012Q4.

We construct a measure of government spending shocks at the firm level linking federal procurement contracts with firms' financial information. We use several restrictions to make sure that the demand shock is unanticipated by firms. In particular, we only include a contract if it was awarded in a full and open competition with at least two bidders. These restrictions enable us to filter out potential anticipation effects and focus on unexpected changes to a firm's future cash flows. We scale the sum of all of a firm's contracts in a given quarter by its lagged capital.

Our empirical analysis is based on a panel data approach to estimate an investment equation, as in Chaney et al. (2009). We account for time-invariant dimensions of heterogeneity among firms by using firm-fixed effects, which nests all unobserved industry-specific effects, such as monopolistic structure. In addition, the analysis of government spending has to consider the issue of time- or 
regime-dependency. Recent studies suggest that government spending can have differential effects depending on the stance of the business cycle. ${ }^{3}$

Our detailed micro-analysis enables us to address this concern by using period-fixed effects. In our set up, the inclusion of a fixed effect for each quarter in the sample captures all time-variant macroeconomic variables such as - changes in the interest rate, changes in legislations, or shocks to the U.S. economy - that are common among all firms. In contrast with studies that use aggregate time series within one country, and hence cannot employ a period-fixed effect as it eliminates all variations in the sample, we can disentangle heterogeneous responses by exploiting cross-sectional variation in the data.

We provide evidence for three main results. First, the estimates suggest that 1 dollar of federal spending increases capital investment by about 7 cents. When we zoom in on relatively large contracts (that is, focusing on a firm's largest contracts), the effect on investment increases to about 12 cents. Second, the evidence indicates that firms that face financing constraints display the highest increase in investment following a new government award. This pattern occurs for different measures of financing constraints that are commonly used in the literature, based on firm size, payout ratio, and corporate bond rating. We complement this analysis by showing that capital investment is mainly financed via short-term debt. Our results suggest that a contract of 1 percent of a firm's capital increases short-term liabilities by .05 percent. Third, industry-level analysis suggests that firms' investment is leading to an increase in investment at the industry-level ruling out a crowdingout hypothesis. Additionally, the evidence indicates that industries with higher dependence on external financing tend to respond more to industry-level government spending, in line with Aghion et al. (2014).

We confirm the robustness of our results by considering a range of specifications, including dynamic models and various subsets of contracts. One general concern with this type of analysis is that awards can be anticipated. We test whether competitive federal contracts are anticipated by examining stock markets' returns. The idea is that if contracts are anticipated, then they should be priced in the financial markets. We find no evidence for anticipation effects, a finding that reinforces the interpretation of our results.

While a number of studies examine the response of private consumption to fiscal stimuli (for example, Sahm et al. (2010) or Parker et al. (2013)), less attention has been paid to the reaction of private investment to government demand. Understanding the link between government spending and investment at the firm level is a central issue in several contexts in economics. From a macroeconomic standpoint, the Keynesian doctrine views government spending as a stimulator for the economy; however, it is well known that not all economists subscribe to this macroeconomic

\footnotetext{
${ }^{3}$ See, for example, Auerbach and Gorodnichenko (2012), DeLong and Summers (2012), Christiano et al. (2011), and Michaillat (2014).
} 
notion. ${ }^{4}$ One source of the disagreement comes from the ambiguous predictions regarding the response of private investment to changes in government purchases. Our micro-based evidence sheds light on one transmission mechanism whereby government purchases can affect aggregate private investment. An effective fiscal intervention is, generally, one that helps reduce the external financing costs of firms. This finding is consistent with recent insights into the role of credit market conditions in the propagation of economic shocks (Gertler and Kiyotaki (2010)). An effective public intervention should address the disparity in firms' access to external funding.

Our paper is related to three strands of the literature. The first strand is empirical and focuses on the effects of financing constraints on firms' investments. Fazzari et al. (1988) argue that financing constraints lower firms' investments. Recently, the findings in Almeida and Campello (2007), Chaney et al. (2012), and Rauh (2006) lend empirical support for this hypothesis. These papers, however, do not consider the potential role of fiscal policy in easing financing constraints. Zwick and Mahon (2014) and Dobridge (2015) consider the effects of tax incentives on investment. They find that financially constrained firms tend to increase investments more than unconstrained firms as a reaction to tax refunds' stimulus policy in the United States. Against this background, we contribute to the literature by studying the spending side of fiscal policy at the firm level and showing that government purchases can also influence financing constraints through cash flow. Related to our paper, Ferraz et al. (2015) study the new hiring patterns of Brazilian firms that win a procurement contract. Our paper uses firms in the United States, looks at capital investment, and focuses on a specific channel via financing constraints.

The second strand of the literature is concerned with estimating the effects of fiscal policy on macroeconomic activities. Available evidence in this area is largely based on vector autoregression models using aggregate data, and the discussion is centered on the size of government spending multipliers - that is, the final effect on key macroeconomic variables such as output and investment. ${ }^{5}$ Increasingly, to strengthen identification, studies are relying on a disaggregated level such as regions or industries. Brueckner and Tuladhar (2014) estimate local government spending multipliers in Japan using data at the prefecture level and find that multipliers tend to be lower in prefectures characterized by a high degree of financial distress. Wilson (2012) estimates the job multiplier of ARRA grants. Cohen et al. (2011) find that government spending shocks, identified at the state-level in the United States, lead to corporate retrenchment. Aghion et al. (2014) examine a panel of OECD countries and find that the effect of a countercyclical fiscal policy is higher in industries that are more dependent on external finance. While our study is not about estimating the spending multiplier, it provides the first micro-level evidence on one transmission mechanism

\footnotetext{
${ }^{4}$ See, for example, Barro (2009) and Krugman (2008).

${ }^{5}$ Ramey (2011a) and Hebous (2011) provide overviews. In a distinct but related application using spending data, Auerbach and Gorodnichenko (2015) construct a quarterly spending shock at the US level from daily spending series and study the reaction of the exchange rate.
} 
through which government spending can affect the economy, namely, via private investment of constrained firms.

The third related strand of the literature is within the ambit of theoretical macroeconomics and financial economics modeling the links between financial frictions and fiscal policy in a Dynamic Stochastic General Equilibrium (DSGE) framework. Studying the interaction between credit market conditions and macroeconomic fluctuations is currently a very active and extensive area of research, such that a survey is beyond our scope (see, e.g., Hall (2011)). However, while earlier studies do not include a fiscal block, an increasing number of papers address interlinks between government spending and credit market conditions. Examples include Fernández-Villaverde (2010), Canzoneri et al. (2015), Carrillo and Poilly (2013), and Challe and Ragot (2011). Generally, the message arsing from this literature is that the spending multiplier is larger when government spending improves financial intermediation. Our contribution provides firm-level evidence in line with this theoretical prediction.

The paper proceeds as follows. In section 2, we motivate the role of government spending in a framework with a collateral-in-advanced constraint. In section 3, we describe the data, and in section 4 we present our empirical specification and main results. Section 5 presents robustness checks. Finally, we conclude in section 6.

\section{Hypothesis DeVelopment}

Lenders provide firms with funds as governed by the discounted value of their collateral. In the absence of a binding collateral-in-advance constraint, the optimal demand for input follows from equating the marginal product with the real price of that input, a familiar result maintained in any model without frictions. However, the financial accelerator model of Bernanke et al. (1996) posits that when the collateral-in-advance constraint is binding, a firm faces a financing premium and the demand for input and capital investment is given by this constraint.

The simplest way to illustrate a link between government spending and firms' investment in their inputs is to consider a prototypical two-period collateral-in-advance constraint:

$$
x_{t+1}=a_{t} f\left(x_{t}\right)+\left(\frac{P_{t+1}}{r_{t+1}}\right) K-r_{t} B_{t}
$$

where $x_{t+1}$ is the demand for input $x$ in the second period, at $a_{t} f\left(x_{t}\right)$ is available cash flow from last period (the price of output is normalized, and $f\left(x_{t}\right)$ is the production function with the usual properties), $\left(\frac{P_{t+1}}{r_{t+1}}\right) K$ is the discounted value of the collateral $K$, and $r_{t} B_{t}$ is the cost of servicing existing debt $B_{t}$ for an interest rate $r_{t}$. $a_{t}$ can be viewed as market capacity and is generally considered to be a function of a number of characteristics, such as consumers' taste and industrial structure. Because the constraint is binding, the demand for $x_{t+1}$ is given by equation 1 . In our context, the main point is that government spending can also act as a factor that influences market capacity. 
As the financing premium is firm specific, the effect of a newly awarded government contract is heterogeneous across firms depending on whether or not the constraint was initially binding. If the constraint was initially binding, the additionally generated cash flow from new government demand reduces the external financing premium through $a_{t_{t}}$ hence easing the constraint and increasing the firm's demand for inputs and production.

In the absence of new government demand, ceteris paribus, a firm would be still facing a binding constraint. Note that if the government contract is awarded to a financially nonconstrained firm, there is no effect on the financing. The reason is that such a firm is already at the optimum and follows the optimal path to address demand changes. Thus, we expect that government purchases have a positive effect on firms' investment, particularly for financially constrained firms.

Recent full pledged models predict similar outcomes in spite of different details. For example, Carrillo and Poilly (2013) show in DSGE setup that increases in government spending stimulate capital accumulation leading to an increase in the price of capital and thus an increase in the value of collateral. The increase in the value of collateral reduces credit spreads and raises firms' investments. In a similar spirit, Challe and Ragot (2011) show that the government spending multiplier is relatively large when government expenditures increase liquidity and loosen firms borrowing constraints. Canzoneri et al. (2015) present a DSGE model predicting that the government spending multiplier is larger when spending affects financial frictions.

Against this background, in the following we empirically assess the link between government spending and firms' capital investment. It is important to stress that this link is independent from the nature of the final good or service that is purchased by the government (i.e., whether it is government consumption or government investment, or whether it is wasteful or not wasteful from a macroeconomic standpoint). For instance, a bridge may or may not present productive spending affecting long-term productivity and output in the economy. However, this paper is not about the effect of the "bridge" on the economy, but it is about the effect of spending on the "firm that builds the bridge", or more generally the effect of spending on the firm upon which government demand falls. This effect is one element that feeds into an aggregate "multiplier". 6

\section{DATA}

The mechanism that we outlined above operates via a shift in government demand for firm specific products. Thus, testing it requires detailed data on government purchases at the firm level. This section describes the data collection of contract-level federal awards, the aggregation to the firmquarter level, and the matching with firms' accounting information. The matching procedure can be

\footnotetext{
${ }^{6}$ For studies on the nature of spending and aggregate output, see for example Leduc and Wilson (2013) and Boehm (2015).
} 
useful for other researchers that want to combine federal awards data with other firm-level information.

\section{A. Federal Procurement Data}

The Federal Funding Accountability and Transparency Act of 2006 required the creation of a public database that includes comprehensive information on federal expenditure. The database contains contract-level transactions for each federal award of more than $\$ 3,000$. Available information includes: the entity that receives the award, the amount that was awarded, the awarding agency, and specifics of the award (for example, whether the winner of the award was determined in a competitive bidding process). ${ }^{7}$ The database is publicly available and it covers the time period from 2000 onwards.

We proceed in steps imposing several restrictions on the data. First, we restrict the contracts database to firms that can be matched with financial information in Compustat. This step removes many small companies for which accounting information is not available. Second, we include only those contracts that were awarded in a full and open competition with at least two bidders. Our hypothesis implies that only unexpected changes to a firm's future cash flows should affect investment, and the purpose of the restriction is to capture the unanticipated component of a firm's future government demand ${ }^{8}$. Moreover, we directly test for anticipation effects in section 5 . Third, we drop observations that seem to be reporting errors; e.g., when the signing date of a contract is after its effective date.

The total value of contracts (after our restrictions) is 750 billion dollars of which we match roughly 620 billion dollars (83 percent). In order to match the awards with firm-level financial information, we collapse the awards data to the quarterly level by summing over the amounts of all awards that a firm has received in each quarter. The mean of awarded firm-quarter contracts is about 26 million dollars and the distribution of awards is right-skewed as is evident from the median that is much lower than the mean (Table 1). Table 2 shows the number of awards by firm-year. Typically, a firm in our sample receives between 1 and 5 contracts per year, but some firms receive more contracts per year.

Table 2 shows the number of awards by firm-year. Typically, a firm receives between 1 and 5 contracts per year, but some firms receive more than 25 contracts per year.

\section{Table 1: Summary statistics for main variables}

\footnotetext{
${ }^{7}$ In this database, the OMB defines a federal contract as "An agreement between the federal government and a prime recipient to execute goods and services for a fee." See: www.usaspending.gov.

${ }^{8}$ The issue of anticipation has been discussed in fiscal policy research raising concerns that foresight can lead to biased estimates (for example, Leeper et al. (2013)).
} 


\begin{tabular}{lcccccc}
\hline Variable & Mean & Median & Std & p25 & p75 & N \\
\hline Contract amount (quarter) & 26.600 & 0.314 & 146.000 & .051 & 2.420 & 21930 \\
Capital investment & 0.159 & 0.106 & 0.162 & 0.052 & 0.205 & 101922 \\
ST liabilities growth & 4.194 & 1.384 & 24.456 & -6.919 & 10.789 & 96278 \\
Total liabilities growth & 3.725 & 0.577 & 19.506 & -3.626 & 6.105 & 107302 \\
RoA & 1.175 & 1.947 & 4.909 & 0.560 & 3.315 & 101394 \\
Cash & -0.098 & 0.132 & 2.276 & 0.030 & 0.394 & 98473 \\
Size & 6.578 & 6.611 & 2.085 & 5.144 & 8.027 & 109934 \\
Market to book & 2.063 & 1.517 & 1.643 & 1.148 & 2.272 & 107339 \\
Payout ratio & 0.854 & 0.000 & 2.812 & 0.000 & 0.440 & 100131 \\
Rating & 11.111 & 11.000 & 3.322 & 8.000 & 13.000 & 38857 \\
\hline
\end{tabular}

Note: Contract amount is the quarterly sum of the values of awarded contracts to a firm and it is expressed in millions of U.S. dollar. Capital investment and cash are scaled by PPE. Sort Term (ST) liabilities and total liabilities are quarterly growth rates. All ratio variables are expressed in percent except for capital investment and cash. RoA is return on assets divided by total assets. Size is the natural logarithm of total assets. Rating is a numerical variable reflecting the S\&P corporate bond rating; high values reflect better rating. Section 8 provides the definitions and sources of all variables.

\section{Table 2: Number of contracts per firm-year}

\begin{tabular}{lrr} 
Number of contracts & Number of firm-years & In pct \\
\hline $1-5$ & 1,534 & 64 \\
$6-10$ & 240 & 10 \\
$10-15$ & 141 & 6 \\
$16-20$ & 68 & 3 \\
$21-25$ & 45 & 2 \\
$>25$ & 385 & 16 \\
Total & 2,413 & 100 \\
\hline
\end{tabular}

\section{B. Firm-Level Data}

We obtain firm-level accounting information at the quarterly level from Compustat. Our main variable of interest is the received amount scaled by lagged property, plants, and equipment (PPE) for each firm and quarter $\left(\frac{\text { Award }_{i t}}{K_{i, t-1}}\right)$. Figure 1 is a histogram of $\frac{A w a r d}{K_{i, t-1}}$. In the benchmark case, we do not restrict the sample of contracts (beyond the procedure described above) to compute $\frac{\text { Award }_{i t}}{K_{i, t-1}}$. We call this the sample of all contracts. In addition, we consider another definition of a firm-specific shock by considering "large contracts", defined as the sum of all amounts in a quarter that lie above the $90^{\text {th }}$ percentile of all awarded contracts for a firm in a specific year.

We define capital investment as capital expenditures normalized by the lagged value of PPE, as is standard in the literature on firms' investments (see, for example, Kaplan and Zingales (1997)). In addition, we construct control variables such as cash, return on assets, and the market-to-book ratio. 
Appendix 8.2 describes all variables in detail. Table 1 displays descriptive statistics of the main accounting variables that are used in our study.

Figure 1: Awarded Contracts

(Scaled by Property, Plants and Equipment)

(a) All contracts

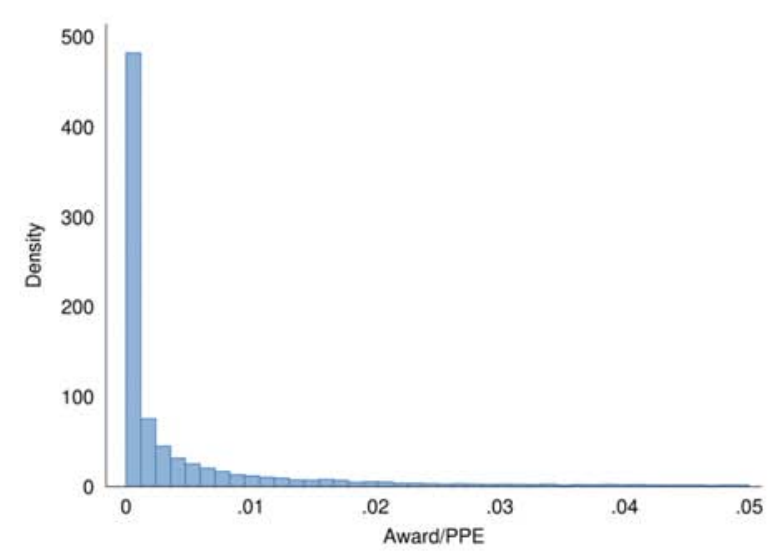

(b) Firms' largest contracts

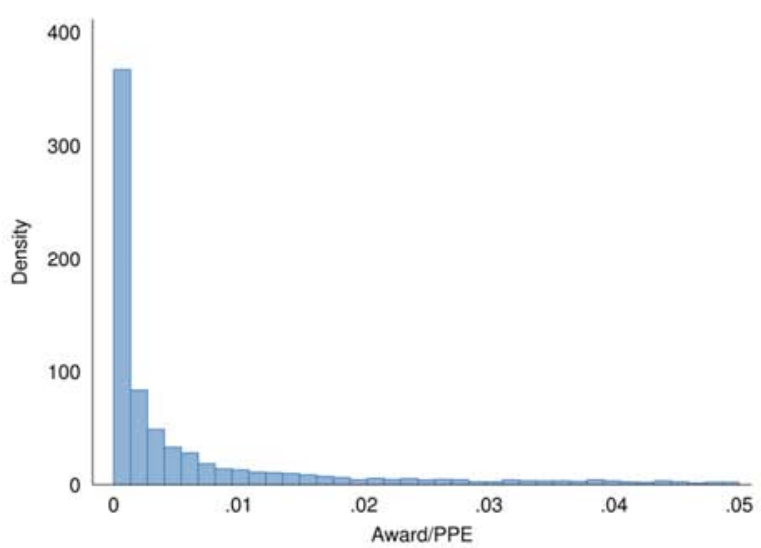

Contract recipients operate in various sectors of the economy. Figure 2 displays major economic sectors (SIC, 2 digit) according to their share of the number of received contracts. Major recipients of awards are manufacturing, including sectors such as industrial machinery and computer equipment, as well as business services.

We define financially constrained firms in three different ways and compare results across those definitions. The three definitions are taken from the literature, e.g. Almeida et al. (2004) and Almeida and Campello (2007). First, using firm size as a proxy for constraints, we rank firms based on their total assets and consider those in the lower (upper) $30^{\text {th }}$ percentile as constrained (unconstrained). Second, in a similar fashion, we rank firms based on their payout ratios and consider those in the lower (upper) $30^{\text {th }}$ percentile as financially constrained (unconstrained). Last, we consider firms to be constrained if the S\&P domestic long-term issuer credit rating is in the high yield range or lower. 


\section{Figure 2: Industry Distribution}

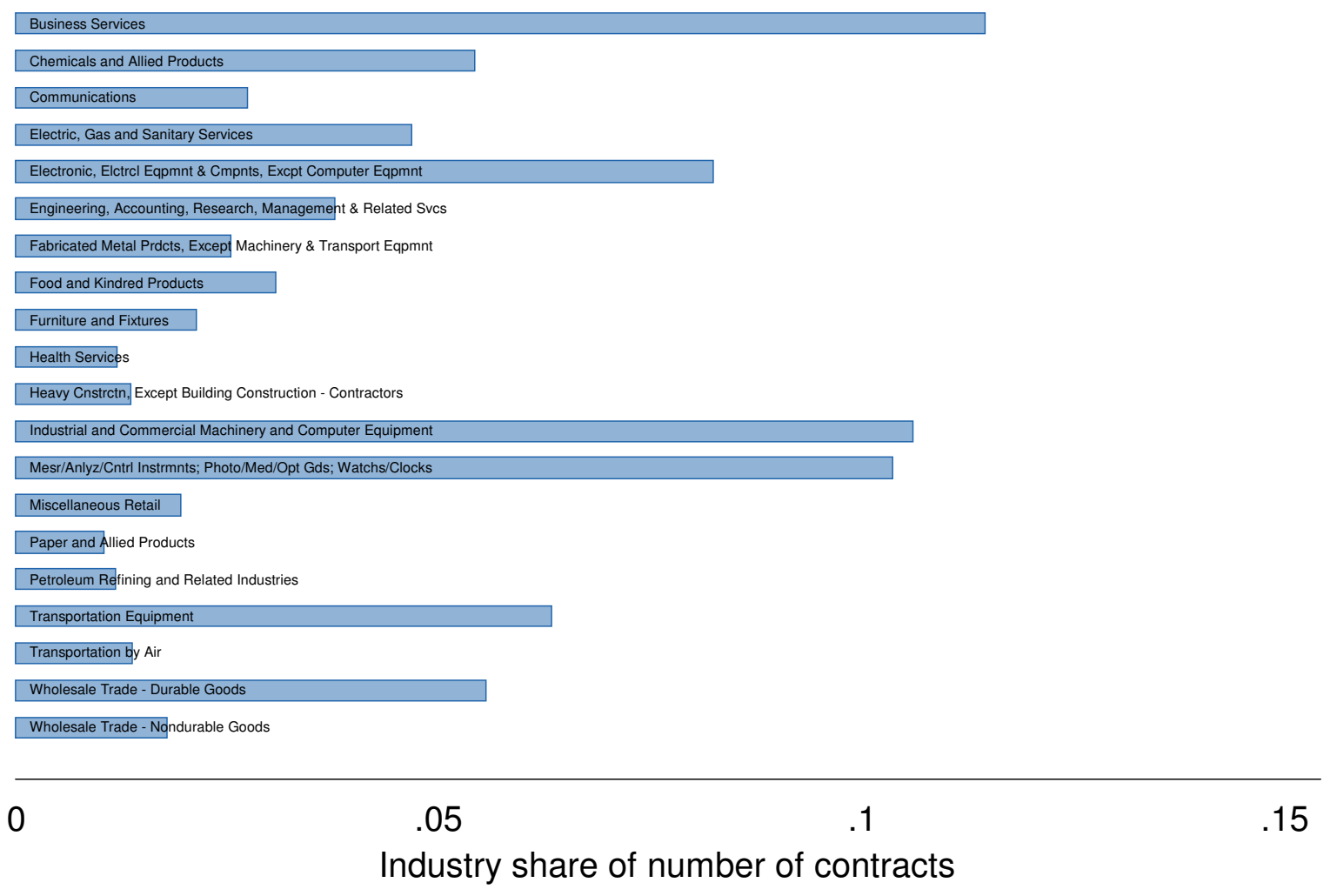

\section{Empirical Analysis}

\section{A. Specification}

We start with the following reduced-form specification to test our hypotheses:

$$
\frac{I_{i t}}{K_{i, t-1}}=\alpha_{0}+\beta \frac{\operatorname{Award}_{i t}}{K_{i, t-1}}+\alpha_{i}+\lambda_{t}+\gamma^{\prime} X_{i t}+u_{i t}
$$

where Award $i t$ is the sum of the values of all awarded government contracts to firm $i$ in quarter $t{ }^{9}$ We include firm-fixed effects $\left(\alpha_{i}\right)$ and time-fixed effects $\left(\lambda_{t}\right)$ and a set of control variables $\left(X_{i t}\right)$.

We estimate equation (2) using the sample of all firms or subsamples including constrained or nonconstrained firms. We are interested in $\beta$, and we expect that the marginal effect is larger for financially constrained firms than for unconstrained firms. The coefficient $\beta$ is identified from two different sources of variation: First, we exploit differences across-firms that won contracts and those

\footnotetext{
${ }^{9}$ Chaney et al. (2009) show that this reduced-form corresponds to a simple model of investment under collateral constraint.
} 
firms that did not win a contract in a certain quarter $t$. The second source of variations is within a firm $i$ - that is, periods when a firm $i$ has not been awarded contracts versus periods when a firm $i$ has been awarded a contract. We run this model for the sample including all contracts and also for a sample including only relatively large contracts as described in the previous section.

The effects of government demand on firms' output can be regime-dependent. Bernanke et al. (1999) provide a comprehensive overview clarifying the relation between the finance premium and the business cycle suggesting that the external finance premium can be countercyclical. Therefore, during periods of financial turmoil, the premium is higher than in normal times and the constraint becomes binding for a larger number of firms. Liebman and Mahoney (2013) find that quality of federal spending in the IT sector declines at the end of the fiscal year. We deal with potentially time-dependent impacts of spending by using period-fixed effects, $\lambda_{t}$, capturing all factors that are common across firms in a quarter. As guided by theory, the vector of controls, $X_{i t}$, is based on Chaney et al. (2012) and includes cash and lagged market-to-book value of assets (Mkt to Book), lagged returns on assets (RoA), and the lagged size of the firm. Note that all industry-specific timeinvariant unobserved heterogeneous effects, such as the market structure, are nested within the set of firm-fixed effects, $\alpha_{i}$.

Our analysis is conditional on the observation of winning a contract. One potential endogeneity concern is that signing a contract can be predicted leading to a correlation with the error terms $u_{i t}$. However, because all contracts in our sample were awarded through a competitive procedure, we expect that predictability is unlikely to be a serious concern in our application. Nonetheless, in section 5 , we consider this issue by testing whether stock returns can predict subsequent contracts and find no evidence that awards are anticipated.

\section{B. Baseline Results}

Table 3 presents our benchmark results. All standard errors are clustered the firm-level correcting for a correlation between error terms within a firm over time. In panel $A$, the first column refrains from including controls or sets of fixed effects. The estimated coefficient suggests that a 1 dollar increase of federal spending increases investment by 7.5 cents. In columns (2) to (4), we interchangeably include firm-fixed effects and/or period-fixed effects. In column (5), we include the full sets of fixed effects as well as the control variables. The estimated coefficients remain statistically significant at the 1 percent level and become only slightly smaller, with an estimated impact of 6.5 cents in the last column.

In panel $B$, we use only contracts that are relatively large for each firm - that is, we include only contracts that are above the $90^{\text {th }}$ percentile of all awards won by a firm in a specific year. The rationale behind this exercise is that the sample of all contracts includes very small contracts compared to the firm size, and those might be less crucial in deriving investment decisions. ${ }^{10}$ The evidence lends support to this argument. The estimates in panel B of table 3 are generally larger than

\footnotetext{
${ }^{10}$ At the macro-level, the issue of the size of a fiscal measure (that is, the intensity of treatment) is related to the discussion in Parker (2011).
} 
those in panel A. When we include firm- and period-fixed effects and controls in column (10), our estimate suggests that 1 dollar of federal spending increases investment by 11 cents. The coefficient on the lagged market-to-book value of assets is positive in line with the literature.

Table 3: Effect of Winning Government Contracts on Capital Investment

\begin{tabular}{|c|c|c|c|c|c|}
\hline & \multicolumn{5}{|c|}{ Panel A: All contracts } \\
\hline & (1) & (2) & (3) & (4) & (5) \\
\hline Award $_{t}$ & $\begin{array}{c}0.075^{\text {*** }} \\
(0.019)\end{array}$ & $\begin{array}{c}0.075^{\text {t+*t }} \\
(0.015)\end{array}$ & $\begin{array}{c}0.075^{\text {**** }} \\
(0.019)\end{array}$ & $\begin{array}{c}0.069^{* * * *} \\
(0.014)\end{array}$ & $\begin{array}{c}0.064^{\text {*** }} \\
(0.015)\end{array}$ \\
\hline $\mathrm{Cash}_{t}$ & & & & & $\begin{array}{c}-0.005^{\text {*** }} \\
(0.001)\end{array}$ \\
\hline Mkt to Book $_{t-1}$ & & & & & $\begin{array}{c}0.020^{* * *} \\
(0.001)\end{array}$ \\
\hline $\operatorname{RoA}_{t-1}$ & & & & & $\begin{array}{c}0.449^{*+*} \\
(0.041)\end{array}$ \\
\hline Size $_{t-1}$ & & & & & $\begin{array}{c}0.004 \\
(0.003)\end{array}$ \\
\hline Constant & $\begin{array}{c}0.155^{\text {*** }} \\
(0.002)\end{array}$ & $\begin{array}{c}0.155^{\text {*** }} \\
(0.000)\end{array}$ & $\begin{array}{c}0.155^{\text {**** }} \\
(0.002)\end{array}$ & $\begin{array}{c}0.157^{\text {*** }} \\
(0.006)\end{array}$ & $\begin{array}{c}0.080^{* * *} \\
(0.020)\end{array}$ \\
\hline Firm FE & No & Yes & No & Yes & Yes \\
\hline Time FE & No & No & Yes & Yes & Yes \\
\hline R2 & 0.001 & 0.001 & 0.089 & 0.128 & 0.163 \\
\hline \multirow[t]{3}{*}{$\mathrm{N}$} & 94366 & 94366 & 94366 & 94366 & 88388 \\
\hline & \multicolumn{5}{|c|}{ Panel B: Firms' largest contracts } \\
\hline & (6) & (7) & (8) & (9) & (10) \\
\hline Award $_{t}$ & $\begin{array}{l}0.067^{*} \\
(0.039)\end{array}$ & $\begin{array}{c}0.117^{\text {t*t+}} \\
(0.031)\end{array}$ & $\begin{array}{c}0.068^{*} \\
(0.039)\end{array}$ & $\begin{array}{c}0.111^{\text {*** }} \\
(0.030)\end{array}$ & $\begin{array}{c}0.103^{\text {*** }} \\
(0.031)\end{array}$ \\
\hline Cash $_{t}$ & & & & & $\begin{array}{c}-0.005^{\text {*** }} \\
(0.001)\end{array}$ \\
\hline Mkt to Book $_{f-1}$ & & & & & $\begin{array}{c}0.020^{* * *} \\
(0.001)\end{array}$ \\
\hline $\operatorname{RoA}_{t-1}$ & & & & & $\begin{array}{c}0.450^{\text {*** }} \\
(0.041)\end{array}$ \\
\hline Size $_{t-1}$ & & & & & $\begin{array}{c}0.004 \\
(0.003)\end{array}$ \\
\hline Constant & $\begin{array}{c}0.155^{\text {*** }} \\
(0.002)\end{array}$ & $\begin{array}{c}0.155^{\text {*** }} \\
(0.000)\end{array}$ & $\begin{array}{c}0.155^{\text {**** }} \\
(0.002)\end{array}$ & $\begin{array}{c}0.232^{\text {*** }} \\
(0.012)\end{array}$ & $\begin{array}{c}0.158^{* * *} \\
(0.021)\end{array}$ \\
\hline Firm FE & No & Yes & No & Yes & Yes \\
\hline Time FE & No & No & Yes & Yes & Yes \\
\hline $\mathrm{R} 2$ & 0.000 & 0.000 & 0.088 & 0.127 & 0.163 \\
\hline $\mathrm{N}$ & 94204 & 94204 & 94204 & 94204 & 88252 \\
\hline
\end{tabular}

Note: $* p \leq 0.1, * * p \leq 0.05, * * * p \leq 0.01$. The dependent variable is capital investment defined as capital expenditure normalized by the lagged book value of PPE Amount Won is the obliged amount of a federal contract normalized by the lagged book value of PPE. Section 8 provides the definitions of all variables. All standard errors are clustered at the firm-level correcting for a correlation between error terms within a cell. 
Table 4: Effect of winning government contracts on capital investment: Constrained vs Unconstrained Firms

\begin{tabular}{|c|c|c|c|c|c|c|}
\hline & \multicolumn{6}{|c|}{ Panel A: All contracts } \\
\hline & \multicolumn{2}{|c|}{ Firm size } & \multicolumn{2}{|c|}{ Payouts } & \multicolumn{2}{|c|}{ Credit rating } \\
\hline & Small & Large & Low & High & Low & High \\
\hline$\overline{\text { Award }_{t}}$ & $\begin{array}{c}0.074^{* * *} \\
(0.022)\end{array}$ & $\begin{array}{l}-0.000 \\
(0.019)\end{array}$ & $\begin{array}{c}0.074^{* * * *} \\
(0.022)\end{array}$ & $\begin{array}{c}0.031 \\
(0.028)\end{array}$ & $\begin{array}{c}0.067^{* * *} \\
(0.016)\end{array}$ & $\begin{array}{l}-0.014 \\
(0.027)\end{array}$ \\
\hline $\mathrm{Cash}_{\mathrm{f}}$ & $\begin{array}{c}-0.007^{* * *} \\
(0.001)\end{array}$ & $\begin{array}{c}0.046^{* * *} \\
(0.014)\end{array}$ & $\begin{array}{c}-0.008^{* * *} \\
(0.001)\end{array}$ & $\begin{array}{c}0.048^{* * *} \\
(0.005)\end{array}$ & $\begin{array}{c}-0.005^{* * *} \\
(0.001)\end{array}$ & $\begin{array}{c}0.082^{* * *} \\
(0.012)\end{array}$ \\
\hline Mkt to Book $_{t-1}$ & $\begin{array}{c}0.018^{* * *} \\
(0.002)\end{array}$ & $\begin{array}{c}0.017^{* * *} \\
(0.002)\end{array}$ & $\begin{array}{c}0.021^{* * *} \\
(0.001)\end{array}$ & $\begin{array}{c}0.007^{* * *} \\
(0.003)\end{array}$ & $\begin{array}{c}0.020^{* * * *} \\
(0.001)\end{array}$ & $\begin{array}{c}0.011^{* * *} \\
(0.003)\end{array}$ \\
\hline $\operatorname{RoA}_{t-1}$ & $\begin{array}{c}0.535^{\text {**** }} \\
(0.050)\end{array}$ & $\begin{array}{l}0.154^{*} \\
(0.088)\end{array}$ & $\begin{array}{c}0.533^{* * *} \\
(0.045)\end{array}$ & $\begin{array}{c}0.094 \\
(0.081)\end{array}$ & $\begin{array}{c}0.473^{* * * *} \\
(0.041)\end{array}$ & $\begin{array}{c}-0.041 \\
(0.160)\end{array}$ \\
\hline Size $_{t-1}$ & $\begin{array}{l}0.011^{* *} \\
(0.005)\end{array}$ & $\begin{array}{c}0.000 \\
(0.004)\end{array}$ & $\begin{array}{l}0.009^{* *} \\
(0.003)\end{array}$ & $\begin{array}{l}-0.006 \\
(0.004)\end{array}$ & $\begin{array}{c}0.003 \\
(0.003)\end{array}$ & $\begin{array}{c}0.005 \\
(0.011)\end{array}$ \\
\hline Constant & $\begin{array}{c}0.160^{* * * *} \\
(0.030) \\
\end{array}$ & $\begin{array}{l}0.069^{*} \\
(0.035) \\
\end{array}$ & $\begin{array}{c}0.166^{* * *} \\
(0.023) \\
\end{array}$ & $\begin{array}{c}0.131^{* * *} \\
(0.031) \\
\end{array}$ & $\begin{array}{c}0.163^{* * * *} \\
(0.019) \\
\end{array}$ & $\begin{array}{c}-0.037 \\
(0.113) \\
\end{array}$ \\
\hline Firm FE & Yes & Yes & Yes & Yes & Yes & Yes \\
\hline Time FE & Yes & Yes & Yes & Yes & Yes & Yes \\
\hline R2 & 0.147 & 0.297 & 0.167 & 0.239 & 0.160 & 0.456 \\
\hline \multirow[t]{4}{*}{$\mathrm{N}$} & 28373 & 29952 & 43906 & 29482 & 78371 & 7051 \\
\hline & \multicolumn{6}{|c|}{ Panel B: Firms' largest contracts } \\
\hline & \multicolumn{2}{|c|}{ Firm size } & \multicolumn{2}{|c|}{ Payouts } & \multicolumn{2}{|c|}{ Credit rating } \\
\hline & Small & Large & Low & High & Low & High \\
\hline Award $_{t}$ & $\begin{array}{l}0.151^{* *} \\
(0.062)\end{array}$ & $\begin{array}{l}-0.009 \\
(0.035)\end{array}$ & $\begin{array}{l}0.127 * * \\
(0.054)\end{array}$ & $\begin{array}{c}0.059 \\
(0.051)\end{array}$ & $\begin{array}{c}0.113^{* * *} \\
(0.035)\end{array}$ & $\begin{array}{l}-0.017 \\
(0.051)\end{array}$ \\
\hline Cash $_{\mathrm{f}}$ & $\begin{array}{c}-0.007^{* * *} \\
(0.001)\end{array}$ & $\begin{array}{c}0.046^{* * *} \\
(0.014)\end{array}$ & $\begin{array}{c}-0.008^{* * *} \\
(0.001)\end{array}$ & $\begin{array}{c}0.048^{* * *} \\
(0.005)\end{array}$ & $\begin{array}{c}-0.005^{* * *} \\
(0.001)\end{array}$ & $\begin{array}{c}0.082^{* * *} \\
(0.012)\end{array}$ \\
\hline Mkt to Book $_{t-1}$ & $\begin{array}{c}0.018^{* * *} \\
(0.002)\end{array}$ & $\begin{array}{c}0.017^{\text {*** }} \\
(0.002)\end{array}$ & $\begin{array}{c}0.021^{* * *} \\
(0.001)\end{array}$ & $\begin{array}{c}0.007^{* * *} \\
(0.003)\end{array}$ & $\begin{array}{c}0.020^{* * *} \\
(0.001)\end{array}$ & $\begin{array}{c}0.011^{* * * *} \\
(0.003)\end{array}$ \\
\hline $\operatorname{RoA}_{t-1}$ & $\begin{array}{c}0.535^{* * *} \\
(0.051)\end{array}$ & $\begin{array}{l}0.149^{*} \\
(0.088)\end{array}$ & $\begin{array}{c}0.534^{* * * *} \\
(0.046)\end{array}$ & $\begin{array}{c}0.094 \\
(0.081)\end{array}$ & $\begin{array}{c}0.474^{* * *} \\
(0.041)\end{array}$ & $\begin{array}{l}-0.053 \\
(0.159)\end{array}$ \\
\hline Size $_{t-1}$ & $\begin{array}{l}0.011^{* *} \\
(0.005)\end{array}$ & $\begin{array}{c}0.000 \\
(0.004)\end{array}$ & $\begin{array}{l}0.009^{* *} \\
(0.003)\end{array}$ & $\begin{array}{l}-0.006 \\
(0.004)\end{array}$ & $\begin{array}{c}0.003 \\
(0.003)\end{array}$ & $\begin{array}{c}0.006 \\
(0.011)\end{array}$ \\
\hline Constant & $\begin{array}{c}0.112^{* * *} \\
(0.031) \\
\end{array}$ & $\begin{array}{c}0.128^{* * *} \\
(0.034) \\
\end{array}$ & $\begin{array}{c}0.072^{* * *} \\
(0.026) \\
\end{array}$ & $\begin{array}{c}0.189 * * * \\
(0.031) \\
\end{array}$ & $\begin{array}{c}0.173^{* * *} \\
(0.023) \\
\end{array}$ & $\begin{array}{c}0.074 \\
(0.103) \\
\end{array}$ \\
\hline Firm FE & Yes & Yes & Yes & Yes & Yes & Yes \\
\hline Time FE & Yes & Yes & Yes & Yes & Yes & Yes \\
\hline $\mathrm{R} 2$ & 0.146 & 0.296 & 0.166 & 0.239 & 0.159 & 0.456 \\
\hline $\mathrm{N}$ & 28350 & 29890 & 43838 & 29425 & 78266 & 7028 \\
\hline
\end{tabular}

Note: $* p \leq 0.1, * * p \leq 0.05, * * * p \leq 0.01$. The dependent variable is capital investment defined as capital expenditure normalized by the lagged book value of PPE. Amount Won is the obliged amount of a federal contract normalized by the lagged book value of PPE. Section 8 provides the definitions of all variables. All standard errors are clustered at the firm-level correcting for a correlation between error terms within a cell. 


\section{Financing Constraints}

The above results motivate the question: Which firms invest more in reaction to new government demand? We estimate equation (2) for the subsamples of constrained and unconstrained firms separately to test the hypothesis that financially constrained firms invest more into capital after receiving an unanticipated government award. Recall that we define financially constrained firms as those that are either small, pay low dividends, or have a low corporate credit rating.

Table 4 displays the results. Panel A shows that small firms increase investment by 7.5 cents for every dollar of government awards. The effect jumps to 15 cents when we consider only large contracts in panel $B$. In both panels $A$ and $B$, we do not find any effect for large companies. Interpreting small firms as more likely to be constrained, these findings indicate that firms with financing constraints do raise investment more in reaction to federal spending.

The result is robust to using other indicators of financing constraints. Using the payout ratio as an indicator, we find that firms that pay low dividends increase investment by 7.4 cents (for all contracts) or 12.7 cents (for large contracts), whereas we find lower and non-significant effects for firms that pay higher dividends. Using the credit rating as an indicator, we find that firms that have a high-yield or no credit rating increase investment by 6.7 cents (for all contracts) or 11.3 cents (for large contracts), whereas we find no effect for firms with an investment grade rating.

\section{External Borrowing}

Our results so far suggest that financing constraints can play an important role in the transmission of government demand to firm investment. Next, we examine whether an awarded contract facilitates firms' access to external financing. We estimate the impact of federal procurements on debt changes using the following model

$$
\frac{\Delta y_{i t}}{y_{i, t-1}}=\alpha_{0}+\beta \frac{\operatorname{Award}_{i t}}{K_{i, t-1}}+\alpha_{i}+\lambda_{t}+\gamma^{\prime} X_{i t}+u_{i t}
$$

where $y_{i t}$ is total debt or short-term debt. Note that, unlike in the baseline regression (2), we are using growth rates as the dependent variable (3) because debt is a state variable from the firms' balance sheets (unlike investment, which is a flow variable).

We start with the results for all firms in Table 5. Winning an amount of 1 percent of capital is associated with short-term debt growth of .06 percentage points, using all contracts or large contracts only. The effect on total liabilities is slightly smaller.

Our initial results show that constrained firms increase their investment more. How do they finance their investment? Table 6 estimates equation (3) for constrained and unconstrained firms separately. Panels A through D show results for short-term and total debt and for all and large contracts separately. Regardless of the measure of financial constraints we find that constrained firms increase debt in response to winning government contracts. Point estimates for unconstrained firms are smaller throughout all specifications and are less precise and 
nonsignificant. Overall, these results are consistent with the hypothesis that federal contracts increase firms' capacity to obtain external funding.

Table 5: Effect of Winning Government Contracts on Firms' Liabilities

\begin{tabular}{|c|c|c|c|c|}
\hline & \multicolumn{2}{|c|}{ All contracts } & \multicolumn{2}{|c|}{ Rel large contracts } \\
\hline & ST liabilities & Total liabilities & ST liabilities & Total liabilities \\
\hline \multirow{2}{*}{ Award $_{t}$} & $5.783^{* * *}$ & $5.049^{* * *}$ & $6.355^{*}$ & 5.634 \\
\hline & $(1.711)$ & $(1.647)$ & $(3.257)$ & (3.464) \\
\hline \multirow[t]{2}{*}{$\mathrm{Cash}_{\mathrm{t}}$} & 0.007 & -0.028 & 0.011 & -0.027 \\
\hline & $(0.095)$ & $(0.080)$ & $(0.095)$ & $(0.080)$ \\
\hline \multirow{2}{*}{ Mkt to Book $_{t-1}$} & $1.338^{* * *}$ & $1.445^{* * *}$ & $1.335^{* * *}$ & $1.448^{* * * *}$ \\
\hline & $(0.116)$ & $(0.111)$ & $(0.117)$ & $(0.112)$ \\
\hline \multirow[t]{2}{*}{$\operatorname{RoA}_{t-1}$} & $-33.317^{* * * *}$ & $-16.342^{* * *}$ & $-33.332^{*+*}$ & $-16.315^{* * *}$ \\
\hline & $(6.919)$ & (5.195) & $(6.924)$ & $(5.189)$ \\
\hline \multirow[t]{2}{*}{ Size $_{t-1}$} & $-2137^{* * *}$ & $-2.839 * * *$ & $-2.133^{*+*}$ & $-2.817^{* * * *}$ \\
\hline & $(0.242)$ & $(0.216)$ & $(0.243)$ & $(0.216)$ \\
\hline \multirow[t]{2}{*}{ Constant } & $13.944^{* * *}$ & $19.220^{* * *}$ & $15.301^{* * *}$ & $16.289^{* * *+*}$ \\
\hline & $(2.020)$ & $(1.876)$ & $(2.738)$ & $(2.012)$ \\
\hline Firm FE & Yes & Yes & Yes & Yes \\
\hline Time FE & Yes & Yes & Yes & Yes \\
\hline $\mathrm{R} 2$ & 0.018 & 0.022 & 0.018 & 0.022 \\
\hline $\mathrm{N}$ & 83027 & 88894 & 82890 & 88743 \\
\hline
\end{tabular}

Note: $* p \leq 0.1, * * p \leq 0.05, * * * p \leq 0.01$. The dependent variable is capital investment defined a s capital expenditure normalized by the lagged book value of PPE. Amount Won is the obliged amount of a federal contract normalized by the lagged book value of PPE. Section 8 provides the definitions of all variables. All standard errors are clustered at the firm-level correcting for a correlation between error terms within a cell. 
Table 6: Effect of Winning Government Contracts on Firms' Liabilities: Constrained vs Unconstrained Firms

\begin{tabular}{|c|c|c|c|c|c|c|}
\hline & \multicolumn{6}{|c|}{ Panel A: All contracts: Effect on ST liabilities } \\
\hline & \multicolumn{2}{|c|}{ Firm size } & \multicolumn{2}{|c|}{ Payouts } & \multicolumn{2}{|c|}{ Credit rating } \\
\hline & Small & Large & Low & High & Low & High \\
\hline$\overline{\text { Award }_{t}}$ & $\begin{array}{c}10.387^{* * * *} \\
(2.807)\end{array}$ & $\begin{array}{c}0.831 \\
(2.302)\end{array}$ & $\begin{array}{c}8.137^{* * *} \\
(2.938)\end{array}$ & $\begin{array}{c}1.536 \\
(2.434)\end{array}$ & $\begin{array}{l}5.711^{* * *} \\
(1.869)\end{array}$ & $\begin{array}{l}-0.841 \\
(2.384)\end{array}$ \\
\hline $\mathrm{R} 2$ & 0.015 & 0.031 & 0.017 & 0.042 & 0.018 & 0.047 \\
\hline \multirow[t]{4}{*}{$\mathrm{N}$} & 28177.000 & 25417.000 & 43207.000 & 27128.000 & 74851.000 & 5890.000 \\
\hline & \multicolumn{6}{|c|}{ Panel B: All contracts: Effect on total liabilities } \\
\hline & \multicolumn{2}{|c|}{ Firm size } & \multicolumn{2}{|c|}{ Payouts } & \multicolumn{2}{|c|}{ Credit rating } \\
\hline & Small & Large & Low & High & Low & High \\
\hline$\overline{\text { Award }_{t}}$ & $\begin{array}{c}9.905^{* * *} \\
(2.521)\end{array}$ & $\begin{array}{c}1.694 \\
(2.430)\end{array}$ & $\begin{array}{c}7.310^{* * * *} \\
(2.688)\end{array}$ & $\begin{array}{c}0.703 \\
(3.185)\end{array}$ & $\begin{array}{c}4.736^{* * *} \\
(1.802)\end{array}$ & $\begin{array}{c}2.357 \\
(2.605)\end{array}$ \\
\hline R2 & 0.019 & 0.042 & 0.023 & 0.036 & 0.022 & 0.059 \\
\hline \multirow[t]{4}{*}{$\mathrm{N}$} & 28492.000 & 30278.000 & 44057.000 & 29822.000 & 78692.000 & 7207.000 \\
\hline & \multicolumn{6}{|c|}{ Panel C: Large contracts: Effect on ST liabilities } \\
\hline & \multicolumn{2}{|c|}{ Firm size } & \multicolumn{2}{|c|}{ Payouts } & \multicolumn{2}{|c|}{ Credit rating } \\
\hline & Small & Large & Low & High & Low & High \\
\hline Award $_{t}$ & $\begin{array}{c}15.742^{* *} \\
(7.482)\end{array}$ & $\begin{array}{c}1.450 \\
(3.833)\end{array}$ & $\begin{array}{l}7.696 \\
(7.074)\end{array}$ & $\begin{array}{c}1.685 \\
(4.436)\end{array}$ & $\begin{array}{l}6.286^{*} \\
(3.766)\end{array}$ & $\begin{array}{l}-1.524 \\
(3.955)\end{array}$ \\
\hline $\mathrm{R} 2$ & 0.015 & 0.031 & 0.017 & 0.041 & 0.018 & 0.046 \\
\hline \multirow[t]{4}{*}{$\mathrm{N}$} & 28154.000 & 25355.000 & 43138.000 & 27072.000 & 74745.000 & 5867.000 \\
\hline & \multicolumn{6}{|c|}{ Panel D: Large contracts: Effect on total liabilities } \\
\hline & \multicolumn{2}{|c|}{ Firm size } & \multicolumn{2}{|c|}{ Payouts } & \multicolumn{2}{|c|}{ Credit rating } \\
\hline & Small & Large & Low & High & Low & High \\
\hline Award $_{t}$ & $\begin{array}{c}16.713^{* *} \\
(7.741)\end{array}$ & $\begin{array}{c}2.514 \\
(4.066)\end{array}$ & $\begin{array}{c}9.222 \\
(7.223)\end{array}$ & $\begin{array}{l}-1.454 \\
(5.974)\end{array}$ & $\begin{array}{c}4.706 \\
(4.013)\end{array}$ & $\begin{array}{c}2.402 \\
(3.704)\end{array}$ \\
\hline $\mathrm{R} 2$ & 0.018 & 0.041 & 0.023 & 0.036 & 0.022 & 0.059 \\
\hline $\mathrm{N}$ & 28469.000 & 30202.000 & 43987.000 & 29754.000 & 78583.000 & 7174.000 \\
\hline
\end{tabular}

\section{Industry-Level Results}

A key question is whether the increase in investment by some firms crowds out investment by others. Consider, for example, a firm that increases investment in inputs following a demand shock. If the additional demand drives up inputs' prices in the industry, investment projects of other firms might become less profitable. This might result in lower capital investments of other firms in the same industry. On the other hand, the increase in investment of some firms can generate new demand for other firms' outputs such that the initial shock creates positive investment spillovers. 
We offer suggestive evidence on industry-wide effect based on aggregating the firm-level data to the industry level. In this exercise, we include all firms in the same industry, regardless of whether or not they won a contract during our sample period. The sample of firms is the universe of firms in Compustat and industries are defined at the 4-digit standard industry classification (SIC) level, and we compute industry investment and government demand shocks on a quarterly basis.

Our first simple test relies on comparing the investment response at the industry level to that at the firm level, reported in section 4.2. If the industry-level investment effect is smaller than the firm-level effect, this would suggest that government demand shocks crowd out other firms' investments in the same industry. If the industry-level investment response was larger, this would suggest positive spillovers to firms in the same industry.

Table 7 presents the results. The estimates using all industries in columns (1) and (4) indicate that the effects of federal procurements transmit to the industry level and do not lend support to the crowding-out hypothesis. The estimated coefficients are similar in magnitude to those in table 4. For instance, our benchmark estimate using all contracts in table 4 estimated a capital investment response of around 6 cents for every dollar of government contract. Column (1) in table 8 suggests that the industry effect is a capital investment response of 7 cents, statistically indistinguishable from the firm-level response.

Furthermore, we present results from re-estimating the model for two subsamples distinguishing between industries based on financial dependence to check whether or not the transmitted effect depends on the external financial dependence of the industry. As an indicator of external financial dependence at the industry level, we use the industry median of capital expenditures minus cash flows over capital expenditures. This index was advocated by Rajan and Zingales (1998) and it has been heavily used in subsequent studies (for example, Aghion et al. (2014) and Duygan-Bump et al. (2015)). Higher values indicate higher debt ratios and hence higher dependence on external financing. Next, we split the sample into industries with low financial dependency, if the index is below the median, or high financial dependency, if the index is above the median. Columns (3) and (6) of Table 8 show that the rise in investment is slightly higher for industries with higher needs for external financing; the difference is small, however. Admittedly, it is challenging to pin down the exact mechanism whereby the effect transmits from the firm level to the industry level as it potentially involves within- and cross-industry spillover effects. The main point of our exercise, however, is that firms' investment is leading to an increase in investment at an aggregate level. This compelling finding implies that government spending can lead to an increase in aggregate private investment, which challenges the traditional crowding-out hypothesis. 


\section{Table 7: Effect of winning government contracts on capital investment (industry-level)}

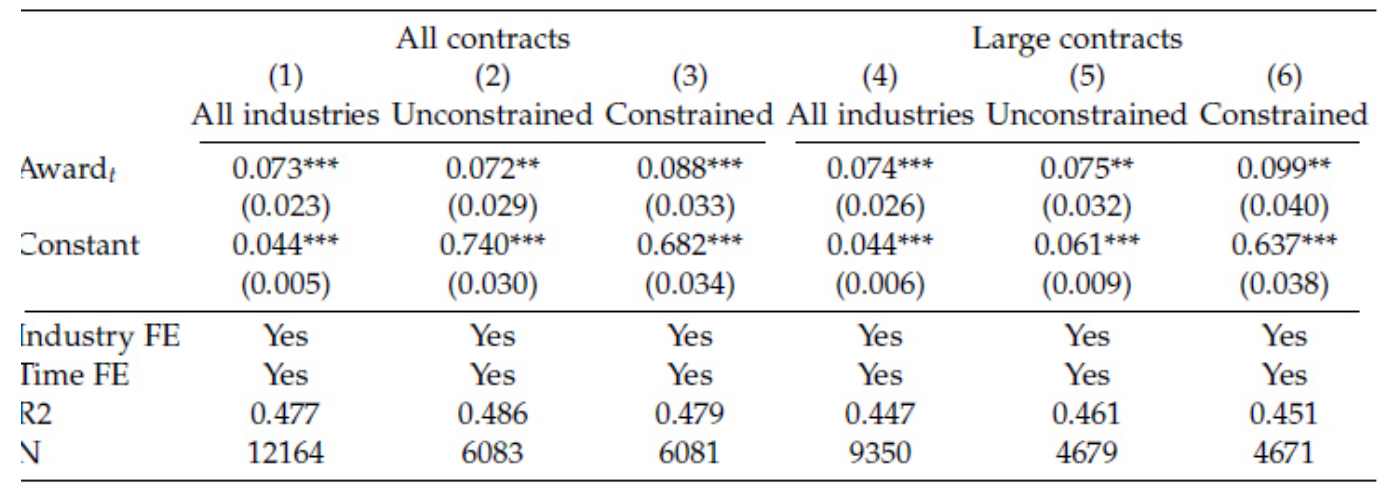

Note: $* p \leq 0.1, * * p \leq 0.05, * * * p \leq 0.01$. The dependent variable is capital investment defined as capital expenditure normalized by the lagged book value of PPE. Amount Won is the obliged amount of federal contracts aggregated at the SIC 4-digit level normalized by the lagged book value of PPE at the SIC 4-digit level. Section 8 provides the definitions of all v ariables. All standard errors a re clustered at the firm-level correcting for a correlation between error terms within a cell.

\section{AntiCipation AND RobUStness}

\section{A. Are Competitive Contracts Anticipated?}

One concern about our benchmark results in section 4.2 is that winning contracts might be anticipated. As such, winning these contracts would not represent actual demand shocks to firms. Our contract selection procedure should safeguard against that concern: Throughout the analysis, we have focused on contracts that were awarded competitively with the bidding process involving at least two firms. To formally test for anticipation effects in our main measure of government demand shocks, we use daily firm-level stock market information. If awarded contacts are anticipated, stock returns should predict subsequent contracts. We construct a daily series of signed contracts for each company and estimate the following model:

$$
\operatorname{Award}_{i t}=\alpha+\sum \theta_{k} \operatorname{Ret}_{i, t-k}+\epsilon_{i t \prime \prime}
$$

where $k=1,2, . ., 20$. Ret $_{i t-k}$ are daily stock returns over the past month and Award ${ }_{i t}$ is the contract amount signed on a particular day. Positive statistically significant $\theta_{k}$ would imply that contracts are anticipated by financial markets.

We use two different measures of returns Ret $_{i t-k}$. Our first measure of $\operatorname{Ret}_{i t-k}$ is a firm's raw daily stock returns. Our second measure uses the Capital Asset Pricing Model (CAPM) to correct for regular swings in the market. In particular, for each firm, we estimate the equation

$$
\operatorname{Ret}_{i t}-R_{t}^{f}=\alpha^{i}+\beta^{i} R_{t}^{m}+v_{i t},
$$


where $R_{t}^{f}$ and $R_{t}^{m}$ are the risk-free and the market return. Our second measure of returns is the residual $\hat{v}_{i t}$ from that regression. ${ }^{11}$

We estimate equation (4) for two different samples, using all days between the year 2000 and the year 2012, and using only the days for each firm when the firm won a contract. This can be effectively interpreted as regressions with two different control groups: Using all days measures whether winning or not winning a contract is associated with past returns. Using only days when contracts are won measures whether winning large and small contracts are differentially associated with past returns.

Panel A of table 8 shows the estimation results for equation (4). For both samples and both measures of returns, we do not find evidence for anticipation effects. Naturally, some coefficients are significant when 80 different ones are estimated, but the timing patterns do not give rise to a consistent pattern. The $F$-statistics for the hypothesis of the joint significance of $\theta_{k}$ indicates that signing a contract is not anticipated by financial markets (except for column (1)). Panel $B$ uses quarterly stock returns and supports these conclusions as well.

Moreover, we find evidence that winning a contract is predictive of future stock returns. This finding complements the results in Table 8. Table 9 displays stock returns of the following strategy: At the beginning of month $t+1$, buy all firms that won a contract in month $t$ and short-sell firms in the sample that did not win a contract in month $t$. The portfolio is updated each month with new information on contract winners in the previous month. Table 9 shows returns of that strategy against standard equilibrium models of returns, that is, the Capital Asset Pricing Model, the FamaFrench three factor model and the four-factor model that adds a momentum factor. Column (1) shows that the average monthly strategy return is .5 percent or approximately 6 percent per year. Columns (2) to (4) show that this strategy return is virtually unaffected by standard factors. ${ }^{12}$ This result indicates that, while the stock market does not anticipate the winner of a contract, it reflects the winning of a contract after the contract has been awarded.

\footnotetext{
${ }^{11}$ We estimate equation (5) for every year of a firms' stock returns separately to account for changes in the structural relationship.

${ }^{12}$ Factor loadings are significant throughout but generally of small magnitude. The negative correlation with the market factor indicates that the strategy is a hedge against market risk. The negative correlation with the size factor indicates that the strategy loads on larger firms, as expected by the sample selection.
} 
Table 8: Awarded contracts and stock returns

Panel A: Using daily returns

\begin{tabular}{|c|c|c|c|c|}
\hline & \multicolumn{2}{|c|}{ Raw returns } & \multicolumn{2}{|c|}{ Adjusted returns } \\
\hline & $(1)$ & $(2)$ & (3) & $(4)$ \\
\hline & All days & Non-zero days & All days & Non-zero days \\
\hline $\operatorname{Ret}_{i t-1}$ & -0.001 & -0.001 & $-0.002^{*}$ & -0.029 \\
\hline $\operatorname{Ret}_{i t-2}$ & -0.000 & -0.004 & -0.001 & -0.001 \\
\hline $\operatorname{Ret}_{i t-3}$ & -0.001 & -0.015 & -0.001 & -0.019 \\
\hline $\operatorname{Ret}_{i t-4}$ & $-0.001^{* *}$ & -0.002 & -0.001 & 0.012 \\
\hline $\operatorname{Ret}_{i t-5}$ & -0.001 & 0.002 & -0.001 & 0.019 \\
\hline $\operatorname{Ret}_{i t-6}$ & -0.001 & 0.001 & -0.001 & 0.025 \\
\hline $\operatorname{Ret}_{i t-7}$ & -0.001 & 0.001 & -0.002 & 0.003 \\
\hline $\operatorname{Ret}_{i t-8}$ & -0.001 & -0.007 & $-0.004^{* * *}$ & -0.014 \\
\hline $\operatorname{Ret}_{i t-9}$ & 0.001 & 0.016 & -0.002 & 0.008 \\
\hline $\operatorname{Ret}_{i t-10}$ & -0.000 & 0.011 & -0.002 & -0.037 \\
\hline $\operatorname{Ret}_{i t-11}$ & 0.000 & $0.029^{*}$ & -0.000 & 0.006 \\
\hline $\operatorname{Ret}_{i t-12}$ & $0.001^{*}$ & 0.024 & 0.001 & 0.028 \\
\hline $\operatorname{Ret}_{i t-13}$ & 0.000 & -0.005 & 0.001 & -0.001 \\
\hline $\operatorname{Ret}_{i t-14}$ & -0.001 & -0.013 & -0.001 & -0.018 \\
\hline $\operatorname{Ret}_{i t-15}$ & $-0.001^{*}$ & -0.018 & $-0.002^{*}$ & $-0.057^{*}$ \\
\hline $\operatorname{Ret}_{i t-16}$ & 0.000 & 0.010 & 0.002 & 0.000 \\
\hline $\operatorname{Ret}_{i t-17}$ & 0.000 & 0.017 & -0.001 & -0.032 \\
\hline $\operatorname{Ret}_{i t-18}$ & $-0.002^{* *}$ & $-0.029^{*}$ & -0.002 & -0.041 \\
\hline $\operatorname{Ret}_{i t-19}$ & 0.000 & 0.006 & 0.002 & 0.021 \\
\hline $\operatorname{Ret}_{i t-20}$ & $-0.001^{* *}$ & -0.005 & -0.001 & 0.002 \\
\hline Constant & $0.000^{* * *}$ & $0.001^{* * *}$ & $0.000^{* * *}$ & $0.001^{* * *}$ \\
\hline Firm FE & Yes & Yes & Yes & Yes \\
\hline Time FE & Yes & Yes & Yes & Yes \\
\hline $\mathrm{R} 2$ & 0.049 & 0.008 & 0.057 & 0.009 \\
\hline $\mathrm{N}$ & 3382448 & 103711 & 1696236 & 80604 \\
\hline F-Statistic & 1.630 & 0.681 & 1.394 & 0.985 \\
\hline $\mathrm{p}$ & $(0.039)$ & $(0.848)$ & $(0.116)$ & $(0.478)$ \\
\hline
\end{tabular}

Panel B: Using quarterly returns

(5) (6)
(7)

Adjusted returns

(8)

\begin{tabular}{lccccc} 
& All days & Non-zero days & & All days & Non-zero days \\
\cline { 2 - 3 } \cline { 6 - 6 } Ret $_{i t-1}$ & 0.000 & 0.050 & & 0.028 & $0.142^{*}$ \\
Ret $_{i t-2}$ & $-0.024^{*}$ & $-0.136^{* *}$ & & -0.017 & -0.050 \\
Constant & -0.000 & $0.008^{* * *}$ & & -0.000 & $0.008^{* * *}$ \\
\hline Firm FE & Yes & Yes & & Yes & Yes \\
Time FE & Yes & Yes & & Yes & Yes \\
R2 & 0.669 & 0.450 & & 0.669 & 0.450 \\
N & 105427 & 20612 & & 105427 & 20612 \\
F-Statistic & 1.631 & 3.433 & & 1.100 & 2.078 \\
p & $(0.196)$ & $(0.033)$ & & $(0.333)$ & $(0.126)$ \\
\hline
\end{tabular}

Note: This table shows results from estimating: $\operatorname{Award}_{i t}=\alpha+\sum \theta_{k} \operatorname{Ret}_{i t-k}+\epsilon_{i t}$, where $k=1,2, . ., 20$. Ret $_{i t-k}$ are daily stock returns over the past month and Award $i t$ is the contract amount signed on a particular day. Ret $_{i t-k}$ is either a firm's raw daily stock returns or adjusted returns defined as the residual $\hat{v}_{i t}$ from the regression: $\operatorname{Ret}_{i t}-R_{t}^{f}=\alpha^{i}+\beta^{i} R_{t}^{m}+v_{i t}$, where $R_{t}^{f}$ and $R_{t}^{m}$ are the risk-free and the market return. The $F$-statistics for the hypothesis of the joint significance of $\theta_{k}$ indicates that signing a contract is not anticipated by financial markets. All standard errors are clustered at the firm-level correcting for a correlation between error terms within a cell. $* p \leq 0.1, * * p \leq$ $0.05, * * *$ Capternational Monetary Fund. Not for Redistribution 
Table 9: Strategy returns against factor models

\begin{tabular}{lcccc}
\hline & $(1)$ & $(2)$ & $(3)$ & $(4)$ \\
\cline { 2 - 5 }$\alpha$ & $0.005^{* *}$ & $0.006^{* *}$ & $0.005^{* *}$ & $0.005^{* *}$ \\
$\beta_{M K T}$ & & $-0.180^{* * *}$ & $-0.145^{* * *}$ & $-0.096^{* *}$ \\
$\beta_{S M B}$ & & & $-0.124^{* *}$ & $-0.146^{* * *}$ \\
$\beta_{H M L}$ & & & $0.092^{*}$ & $0.097^{* *}$ \\
$\beta_{U M D}$ & & & & $0.086^{* * *}$ \\
\hline $\mathrm{N}$ & 156 & 156 & 156 & 156 \\
\hline
\end{tabular}

Note: This table shows strategy returns against the CAPM, the Fama-French three factor model and the four-factor model that adds momentum. The strategy works as follows: At the beginning of month $t+1$, buy all firms that won a contract in month $t$ and short-sell firms in the sample that did not win a contract in month $t$. The portfolio is updated each month with new information on contract winners in the previous month. Regressions are of the form:

$$
r_{i t}-r_{f t}=\alpha+\beta_{M K T}\left(r_{M K T, t}-r_{f t}\right)+\beta_{S M B} r_{S M B, t}+\beta_{H M L} r_{H M L, t}+\beta_{U M D} r_{U M D, t}+\epsilon_{i t},
$$

where $M K T$ indicates returns to the market factor, $S M B$ to the size factor, $H M L$ to the value factor and $U M D$ to the momentum factor. $r_{f t}$ is the riskfree rate. Newey-West standard errors are used throughout. Note: $* p \leq 0.1, * * p \leq 0.05, * * * p \leq 0.01$.

\section{B. Robustness to Model Specification}

While our benchmark regression model in equation (2) is a standard specification in the investment literature, our results are robust to several alternative specifications. Columns (2) and (5) of table 10 show estimates of a dynamic panel-data model that includes two lags of our dependent variable as additional regressors. To compare the estimates with the static model, we need to compute the long-run multiplier - that is, we need to adjust the point estimates $\beta$ for the autoregressive structure of investment as $\frac{\beta}{1-b_{1}-b_{2}}$ (where $b_{1}$ and $b_{2}$ are the coefficients on the lagged values of investment). In columns (2) and (5), we find effects of government demand on capital investment of 7.3 and 12.2 cents per dollar of demand, which are slightly higher but very similar to the benchmark estimates of the static model (reproduced in columns (1) and (4)). As is well known, using lagged values of the dependent variable as regressors in a fixed-effects panel model introduces estimation bias. Columns (3) and (6) of table 10 address the bias by using an Arellano-Bond estimation instead. Coefficient estimates are again very similar: The long-run impact of spending on investment is 4 cents per dollar for all contracts and 11 cents per dollar for large contracts.

\section{Robustness to Contract Selection}

Next, we show that our results are robust to other contract selection criteria. Recall that our analysis only includes contracts that were awarded competitively with at least two bidders. Our two 
baseline samples include all contracts regardless of size and contracts that are large relative to a firm's typical contract. One concern is that this selection does not put hard thresholds on contract size and therefore includes many very small contracts with potentially different effects on capital investment.

Table 11 reproduces the estimation results using only contracts with amounts larger than 50,000 dollars or larger than 500,000 dollars. The coefficient estimates are very similar to the benchmark results. Again, we find an increase in capital investment of around 6 cent for every dollar of government spending. Panels $A$ and $B$ of table 12 show that this increase is concentrated in financially constrained firms.

The literature on fiscal multiplier often focuses on defense spending as a component of government spending that might be less correlated with the business cycle (for example, Ramey (2011b), Nakamura and Steinsson (2014)). As such, it is illustrative to restrict our sample to contracts that were awarded by the Department of Defense (DoD). Columns (5) and (6) of table 11 show that the effect on capital investment is slightly higher when we use these contracts only: Firms increase capital investment by 8 cents per dollar of a Department of Defense contract. This increase is again concentrated in financially constrained firms, as shown in panel C of table 2 . 
Table 10: Effect of winning a government contract on capital expenditure: Robustness to model specifications

\begin{tabular}{|c|c|c|c|c|c|c|}
\hline & \multicolumn{3}{|c|}{ All contracts } & \multicolumn{3}{|c|}{ Firms' largest contracts } \\
\hline & (1) & (2) & (3) & $(4)$ & (5) & (6) \\
\hline & Static & Dynamic & $\mathrm{AB}$ & Static & Dynamic & $\mathrm{AB}$ \\
\hline \multirow[t]{2}{*}{ Award $_{t}$} & $0.064^{* * *}$ & $0.045^{* * *}$ & $0.037^{*}$ & $0.103^{* * *}$ & $0.075^{* * *}$ & $0.100^{* *}$ \\
\hline & $(0.015)$ & $(0.011)$ & $(0.021)$ & $(0.031)$ & $(0.024)$ & $(0.040)$ \\
\hline \multirow[t]{2}{*}{ Cash $_{t}$} & $-0.005^{* * *}$ & $-0.004^{* * *}$ & $-0.006^{* * *}$ & $-0.005^{* * *}$ & $-0.004^{* * *}$ & $-0.006^{* * *}$ \\
\hline & $(0.001)$ & $(0.001)$ & $(0.001)$ & $(0.001)$ & $(0.001)$ & $(0.001)$ \\
\hline \multirow[t]{2}{*}{ Mkt to Book$_{t-1}$} & $0.020^{* * *}$ & $0.013^{* * *}$ & $0.021^{* * *}$ & $0.020^{* * *}$ & $0.013^{* * *}$ & $0.021^{* * *}$ \\
\hline & $(0.001)$ & $(0.001)$ & $(0.002)$ & $(0.001)$ & $(0.001)$ & $(0.002)$ \\
\hline \multirow[t]{2}{*}{$\operatorname{RoA}_{t-1}$} & $0.449^{* * *}$ & $0.321^{* * *}$ & $0.331^{* * *}$ & $0.450^{* * *}$ & $0.321^{* * *}$ & $0.328^{* * *}$ \\
\hline & $(0.041)$ & $(0.033)$ & $(0.047)$ & $(0.041)$ & $(0.033)$ & $(0.047)$ \\
\hline \multirow[t]{2}{*}{ Size $_{t-1}$} & 0.004 & 0.000 & $-0.082^{* * *}$ & 0.004 & 0.000 & $-0.082^{* * *}$ \\
\hline & (0.003) & $(0.002)$ & $(0.007)$ & (0.003) & (0.002) & $(0.007)$ \\
\hline \multirow[t]{2}{*}{ Investment $_{t-1}$} & & $0.408^{* * *}$ & $0.233^{* * *}$ & & $0.408^{* * *}$ & $0.233^{* * *}$ \\
\hline & & $(0.008)$ & $(0.010)$ & & $(0.008)$ & $(0.010)$ \\
\hline \multirow[t]{2}{*}{ Investment $_{t-2}$} & & $-0.021^{* * *}$ & $-0.150^{* * *}$ & & $-0.021^{* * *}$ & $-0.150^{* * *}$ \\
\hline & & $(0.007)$ & $(0.009)$ & & $(0.007)$ & $(0.009)$ \\
\hline \multirow[t]{2}{*}{ Constant } & $0.080^{* * *}$ & $0.065^{* * *}$ & $0.658^{* * *}$ & $0.158^{* * *}$ & $0.118^{* * *}$ & $0.660^{* * *}$ \\
\hline & $(0.020)$ & $(0.014)$ & $(0.053)$ & $(0.021)$ & $(0.016)$ & $(0.054)$ \\
\hline Firm FE & Yes & Yes & Yes & Yes & Yes & Yes \\
\hline Time FE & Yes & Yes & Yes & Yes & Yes & Yes \\
\hline $\mathrm{R} 2$ & 0.163 & 0.301 & & 0.163 & 0.301 & \\
\hline $\mathrm{N}$ & 88388 & 87673 & 85170 & 88252 & 87538 & 85038 \\
\hline
\end{tabular}

Note: $* p \leq 0.1, * * p \leq 0.05, * * * p \leq 0.01$. The dependent variable is capital investment defined as capital expenditure normalized by the lagged book value of PPE. Award is the obliged amount of a federal contract normalized by the lagged book value of PPE. Section 8 provides the definitions of all variables. All standard errors are clustered at the firm-level correcting for a correlation between error terms within a cell. 
Table 11: Effect of winning a government contract on capital expenditure: Robustness to contract selection

\begin{tabular}{|c|c|c|c|c|c|c|}
\hline & \multicolumn{2}{|c|}{ Medium } & \multicolumn{2}{|c|}{ Large } & \multicolumn{2}{|c|}{ DoD } \\
\hline & $(1)$ & (2) & (3) & (4) & (5) & (6) \\
\hline Award $t$ & $\begin{array}{c}0.067^{* * *} \\
(0.015)\end{array}$ & $\begin{array}{c}0.063^{* * *} \\
(0.015)\end{array}$ & $\begin{array}{c}0.061^{* * *} \\
(0.018)\end{array}$ & $\begin{array}{c}0.057^{* * *} \\
(0.019)\end{array}$ & $\begin{array}{c}0.084^{* * *} \\
(0.021)\end{array}$ & $\begin{array}{c}0.079^{* * *} \\
(0.021)\end{array}$ \\
\hline Cash $_{t}$ & & $\begin{array}{c}-0.005^{* * *} \\
(0.001)\end{array}$ & & $\begin{array}{c}-0.005^{* * *} \\
(0.001)\end{array}$ & & $\begin{array}{c}-0.005^{* * *} \\
(0.001)\end{array}$ \\
\hline Mkt to Book $_{t-1}$ & & $\begin{array}{c}0.020^{* * *} \\
(0.001)\end{array}$ & & $\begin{array}{c}0.020^{* * *} \\
(0.001)\end{array}$ & & $\begin{array}{c}0.020^{* * *} \\
(0.001)\end{array}$ \\
\hline $\operatorname{RoA}_{t-1}$ & & $\begin{array}{c}0.450^{* * *} \\
(0.041)\end{array}$ & & $\begin{array}{c}0.450^{* * *} \\
(0.041)\end{array}$ & & $\begin{array}{c}0.450^{* * *} \\
(0.041)\end{array}$ \\
\hline Size $_{t-1}$ & & $\begin{array}{c}0.004 \\
(0.003)\end{array}$ & & $\begin{array}{c}0.004 \\
(0.003)\end{array}$ & & $\begin{array}{c}0.004 \\
(0.003)\end{array}$ \\
\hline Constant & $\begin{array}{c}0.225^{* * *} \\
(0.009)\end{array}$ & $\begin{array}{c}0.152^{* * *} \\
(0.019)\end{array}$ & $\begin{array}{c}0.214^{* * *} \\
(0.013)\end{array}$ & $\begin{array}{c}0.147^{* * *} \\
(0.021)\end{array}$ & $\begin{array}{c}0.227^{* * *} \\
(0.010)\end{array}$ & $\begin{array}{c}0.149^{* * *} \\
(0.019)\end{array}$ \\
\hline Firm FE & Yes & Yes & Yes & Yes & Yes & Yes \\
\hline Time FE & Yes & Yes & Yes & Yes & Yes & Yes \\
\hline $\mathrm{R} 2$ & 0.127 & 0.163 & 0.127 & 0.162 & 0.127 & 0.163 \\
\hline $\mathrm{N}$ & 94302 & 88332 & 94203 & 88247 & 94304 & 88335 \\
\hline
\end{tabular}

Note: $* p \leq 0.1, * * p \leq 0.05, * * * p \leq 0.01$. The dependent variable is capital investment defined as capital expenditure normalized by the lagged book value of PPE.Award is the obliged amount of a federal contract normalized by the lagged book value of PPE. Section 8 provides the definitions of all variables. All standard errors are clustered at the firm-level correcting for a correlation between error terms within a cell. 
Table 12: Effect of winning a government contract on capital expenditure: Constrained vs unconstrained firms. Robustness to contract selection

\begin{tabular}{|c|c|c|c|c|c|c|}
\hline & \multicolumn{6}{|c|}{ Panel A: Contracts larger than USD 50,000 } \\
\hline & \multicolumn{2}{|c|}{ Firm size } & \multicolumn{2}{|c|}{ Payouts } & \multicolumn{2}{|c|}{ Credit rating } \\
\hline & Small & Large & Low & High & Low & High \\
\hline \multirow[t]{2}{*}{ Award $_{t}$} & $0.072^{* * *}$ & 0.004 & $0.071^{* * *}$ & 0.031 & $0.066^{* * *}$ & -0.013 \\
\hline & $(0.023)$ & $(0.020)$ & $(0.023)$ & $(0.030)$ & $(0.016)$ & $(0.031)$ \\
\hline $\mathrm{R} 2$ & 0.146 & 0.296 & 0.166 & 0.239 & 0.160 & 0.455 \\
\hline \multirow[t]{4}{*}{$\mathrm{N}$} & 28364 & 29925 & 43880 & 29455 & 78326 & 7042 \\
\hline & \multicolumn{6}{|c|}{ Panel B: Contracts larger than USD 500,000 } \\
\hline & \multicolumn{2}{|c|}{ Firm size } & \multicolumn{2}{|c|}{ Payouts } & \multicolumn{2}{|c|}{ Credit rating } \\
\hline & Small & Large & Low & High & Low & High \\
\hline \multirow[t]{2}{*}{ Award $_{t}$} & $0.061^{* *}$ & 0.008 & $0.063^{* *}$ & 0.019 & $0.061^{* * *}$ & -0.019 \\
\hline & $(0.029)$ & $(0.024)$ & $(0.028)$ & $(0.036)$ & $(0.020)$ & $(0.036)$ \\
\hline $\mathrm{R} 2$ & 0.146 & 0.296 & 0.166 & 0.239 & 0.159 & 0.456 \\
\hline \multirow[t]{4}{*}{$\mathrm{N}$} & 28353 & 29884 & 43838 & 29420 & 78265 & 7024 \\
\hline & \multicolumn{6}{|c|}{ Panel C: Contracts by the DoD only } \\
\hline & \multicolumn{2}{|c|}{ Firm size } & \multicolumn{2}{|c|}{ Payouts } & \multicolumn{2}{|c|}{ Credit rating } \\
\hline & Small & Large & Low & High & Low & High \\
\hline \multirow[t]{2}{*}{ Award $_{t}$} & $0.087^{* *}$ & 0.002 & $0.080^{* *}$ & 0.039 & $0.082^{* * *}$ & 0.008 \\
\hline & $(0.034)$ & $(0.025)$ & $(0.033)$ & $(0.040)$ & $(0.023)$ & $(0.019)$ \\
\hline $\mathrm{R} 2$ & 0.146 & 0.296 & 0.166 & 0.239 & 0.160 & 0.455 \\
\hline $\mathrm{N}$ & 28368 & 29921 & 43882 & 29458 & 78332 & 7040 \\
\hline
\end{tabular}

Note: $* p \leq 0.1, * * p \leq 0.05, * * * p \leq 0.01$. The dependent variable is capital investment defined as capital expenditure normalized by the lagged book value of PPE. Award is the obliged amount of a federal contract normalized by the lagged book value of PPE. All specifications include the following control variables: Cash, Mkt to Book, RoA, and Size. Section 8 provides the definitions of all variables. All standard errors are clustered at the firm-level correcting for a correlation between error terms within a cell. 


\section{Conclusion}

Fiscal policy can affect the economy through several channels, most prominently via its effects on private consumption or investment. While a number of studies use micro-data to examine the response of private consumption to fiscal stimuli, firm-level evidence on the link between government spending and private investment is rarely available. In another strand of literature, several studies suggest that external financing constraints can hinder firms' investment response to shocks.

Hence, against this background, we analyze the effects of government demand shocks on capital investment at the firm level using rich data on government contracts matched to firms' financial information. To isolate a specific mechanism, we focus on the investment patterns of firms that are financially constrained, and we argue that their investment response is expected to be more pronounced.

A key finding of our analysis is that financially constrained firms react to new government demand by raising capital investment. We show that the average response of capital investment is between 6 and 11 cents per dollar of government demand. The average, however, masks substantial heterogeneity: We find larger effects for firms that are plausibly constrained and non-significant effects for unconstrained firms. The evidence indicates that government contracts enable firms to increase their capacity to obtain external financing.

When we aggregate our data to the industry-level, we find an almost one-to-one pass-through of private capital investment to industry-level capital investment. This suggests that government contracts do not crowd out private investment, an important concern for policy considerations. However, we cannot rule out crowd-out effects in other industries. An important avenue for future research is to address potential cross-industry spillover effects of government spending. 


\section{References}

Aghion, P., D. Hémous, and E. Kharroubi (2014). Cyclical fiscal policy, credit constraints, and industry growth. Journal of Monetary Economics 62, 41-58.

Almeida, H. and M. Campello (2007). Financial constraints, asset tangibility, and corporate investment. Review of Financial Studies 20(5), 1429-1460.

Almeida, H., M. Campello, and M. Weisbach (2004). The cash flow sensitivity of cash. Journal of Finance 59(4), 1777-1804.

Auerbach, A. and Y. Gorodnichenko (2015). Effects of fiscal shocks in a globalized world. IMF Economic Review, forthcoming.

Auerbach, A. and Y. Gorodnichenko (2012). Measuring the output responses to fiscal policy. American Economic Journal: Economic Policy 4(2), 1-27.

Barro, R. (2009). Government spending is no free lunch. The Wall Street Journal.

Bernanke, B., M. Gertler, and S. Gilchrist (1999). The financial accelator in a quantitative business cycle framework. In J. T. . M. Woodford (Ed.), Handbook of Macroeconomics, Volume 1, Chapter 21, pp. 1341-1393. North Holland.

Bernanke, B., M. Gertler, and S. Gilchrist (1996). The financial accelerator and the flight to quality. Review of Economics and Statistics 78(1), 1-15.

Boehm, C. (2015). Fiscal policy and durable goods.

Brueckner, M. and A. Tuladhar (2014). Local government spending multipliers and financial distress: Evidence from japanese prefectures. Economic Journal 124, 1279-1316.

Canzoneri, M., F. Collard, H. Dellas, and B. Diba (2015). Fiscal multipliers in recessions. Economic Journal 1(1), 1-2.

Carrillo, J. and C. Poilly (2013). How do financial frictions affect the spending multiplier during a liquidity trap? Review of Economic Dynamics 16, 296-311.

Challe, E. and X. Ragot (2011). Fiscal policy in a tractable liquidity-constrained economy. Economic Journal 121(551), 273-317.

Chaney, T., D. Sraer, and D. Thesmar (2009). The collateral channel: How real estate shocks affect corporate investment. HEC Working Paper October, NBER.

Chaney, T., D. Sraer, and D. Thesmar (2012). The collateral channel: How real estate shocks affect corporate investment. American Economic Review 102(6), 2381-2409. 
Christiano, L., M. Eichenbaum, and S. Rebelo (2011). When is the government spending multiplier large? Journal of Political Economy 119(1), 78-121.

Cohen, L., J. Coval., and C. Malloy (2011). Do powerful politicians cause corporate downsizing? Journal of Political Economy 119(6), 1015-1060.

DeLong, J. and L. Summers (2012). Fiscal policy in a depressed economy. Brookings Papers on Economic Activity 44(1), 233-297.

Dobridge, C. (2015). Fiscal stimulus and firms: A tale of two recessions.

Duygan-Bump, B., A. Levkovb., and J. Montoriol-Garrigac (2015). Financing constraints and unemployment: Evidence from the great recession. Journal of Monetary Economics 75(October), 89-105.

Fazzari, E., G. Hubbard, and B. Petersen (1988). Financing constraints and corporate investment. Brookings Papers on Economic Activity 1988(1), 141-195.

Fernández-Villaverde, J. (2010). Fiscal policy in a model with financial frictions. American Economic Review: Papers and Proceedings 100(2), 35-40.

Ferraz, C., F. Finan, and D. Szerman (2015). Procuring firm growth: The effects of government purchases on firm dynamics. WP 21219, NBER.

Gertler, M. and N. Kiyotaki (2010). Financial intermediation and credit policy in business cycle analysis. In B. Friedman and M. Woodford (Eds.), Handbook of Monetary Economics, Volume 3, Chapter 11, pp. 547-599. Elsevier.

Hall, R. (2011). The high sensitivity of economic activity to financial frictions. Economic Journal 121(552), 351-378.

Hebous, S. (2011). The effects of discretionary fiscal policy on macroeconomic aggregates: A reappraisal. Journal of Economic Surveys 25(4), 674-707.

Kaplan, S. and L. Zingales (1997). Do investment-cash flow sensitivities provide useful measures of financing constraints? The Quarterly Journal of Economics 112(1), 169-215.

Krugman, P. (2008). The conscience of a liberal. The New York Times.

Leduc, S., and D. Wilson (2013). Roads to prosperity or bridges to nowhere? theory and evidence on the impact of public infrastructure investment. In J. Parker and M. Woodford (Eds.), NBER Macroeconomic Annual 2012, Volume 27, pp. 89-142. University of Chicago Press.

Leeper, E., T. Walker., and S. Yang (2013). Fiscal foresight and information flows. Econometrica 18(3), 1115-1145.

Liebman, J. and N. Mahoney (2013). Do expiring budgets lead to wasteful year-end spending? evidence from federal procurement. WP 19481, NBER. 
Michaillat, P. (2014). A theory of countercyclical government multiplier. American Economic Journal: Macroeconomics 6(1), 190-217.

Nakamura, E. and J. Steinsson (2014). Fiscal stimulus in a monetary union: Evidence from us regions. American Economic Review 104(3), 753-792.

Parker, J. (2011). On measuring the effects of fiscal policy in recessions. Journal of Economic Literature 49(3), 703-718.

Parker, J., N. Souleles., D. Johnson, and R. McClelland (2013). Consumer spending and the economic stimulus payments of 2008. American Economic Review 103(6), 2530-2553.

Rajan, R. and L. Zingales (1998). Financial dependence and growth. American Economic Review 88(3), 559-586.

Ramey, V. (2011a). Can government purchases stimulate the economy? Journal of Economic Literature 49(3), 673-685.

Ramey, V. (2011b). Identifying government spending shocks: It's all in the timing. The Quarterly Journal of Economics 126(1), 1-50.

Rauh, J. (2006). Investment and financing constraints: Evidence from the funding of corporate pension plans. Journal of Finance 61(1), 33-72.

Sahm, C., M. Shapiro., and J. Slemrod (2010). Household response to the 2008 tax rebate: Survey evidence and aggregate implications. Tax Policy and the Economy 24, 69-110.

Wilson, D. (2012). Fiscal spending jobs multipliers: Evidence from the 2009 American recovery and reinvestment act. American Economic Journal: Economic Policy 4(3), 251-282.

Zwick, E. and J. Mahon (2014). Do financial frictions amplify fiscal policy? Evidence from business investment stimulus. WP 14/15, Oxford Centre for Business Taxation. 


\section{Appendix A: Supplementary Online Appendix}

\section{Variable Definitions}

- Award: $\frac{A_{w a r d} i t}{K_{i, t-1}}$ is the obliged amount of a federal contract obtained from the database of the Office of Management and Budget normalized by the lagged book value of properties, plant and equipment, PPE, obtained form Compustat (ppentq).

- Capital investment: $\frac{I_{i t}}{K_{i, t-1}}$ is capital expenditure (capxy) normalized by the lagged book value of properties, plant and equipment, $\mathrm{PPE},(p p e n t q)$.

- Cash: is income before extraordinary items + depreciation and amortization (iby + dpq) normalized by lagged book value of value of properties, plant and equipment, PPE, (ppentq).

- Market to book value of assets: MkttoBook is the market value of assets (atq - ceqq + (cshoq $\times$ prccq) $-t x d b q)$ normalized by their book value (atq).

- Size: is the log of total assets (atq).

- RoA: is return on assets ((oibdpq - $d p q)$ divided by $a t q)$.

- Ex ante measures of credit constraints (Firm-level):

- Firm Size: In every quarter, we rank firms based on their total assets and consider those in the lower (upper) $30^{\text {th }}$ percentile as constrained (unconstrained).

- Dividend payments (payout ratio): In every quarter, we rank firms based on their payout ratios and consider those in the lower (upper) $30^{\text {th }}$ percentile as constrained (unconstrained). The payout ratio is ( $d v p s x q+c s h o p q)$ divided by oibdpq

- Corporate credit rating: We consider firms to be constrained if the S\&P domestic long term issuer credit rating (splticrm is BBB or lower.

- Financial dependency (industry-level): As in Rajan and Zingales (1998), we compute the industry-median (at the 4 digits, Standard Industrial Classification system) of capital expenditures minus cash flows over capital expenditures.

- Returns: Ret is a daily series of stock returns from CRSP.

- Short-term debt: The growth rate of short-term debt (ltq - lltq).

- Total debt: The growth rate of total debt (ltq). 


\section{Matching Procedure between Procurement Contracts and Compustat}

The Federal Funding Accountability and Transparency Act (FFATA) requires the disclosure of information on entities that receive Federal awards. These include types of contracts, grants, loans, and other types of spending.

The data are at the plant level, company name, address and telephone numbers are given. In addition, each entry has a DUNS number which is a plant-level company identifier that is used by some government agencies. The DUNS number of the parent company is also part of the data set. It is called parentdunsnumber and is our primary identifier for companies. We collapse all data at the parent company level and we extract a list of all unique parent DUNS numbers that are part of the dataset, a total of 566,271 different DUNS numbers.

Only few data sets have the DUNS number as an identifier. ${ }^{1}$ One dataset that includes DUNS numbers is Bureau van Dijk's Orbis database. To quote the provider, it is a "global database containing information on millions of companies that is unique in its breadth of geographies and extent of companies covered as well as the availability of private company financial information." We uploaded our list of unique parent DUNS numbers to Orbis and were able to match 313,935 company records. For the companies that we could match, we downloaded the company name (for checking purposes), a BvD ID number, a BvD account number and the ticker symbol alongside with the DUNS number. Ticker information was not available for 310,523 companies, which is about the size that we expected.

We could use the ticker directly in a standard financial database such as CRSP but we are careful to note that tickers might change over time. We therefore included one more step.

Another BvD product, Osiris provides financial accounting data for publicly listed companies around the world. Osiris also includes each company's current ticker for each year.

The OS ID number is identical to the BvD account number and can be used to access the data. We uploaded our list of BvD accout numbers to Osiris (a total of 312,586 because 1349 observations do not have a unique DUNS - BvD account number match), and received data for a total of 2754 companies, by OS ID number and year from 2000 to 2012. We also downloaded the current ticker, the current CIK number, the current stock exchange and the listing status. We obtained 32,106 valid observations over the 13 years.

\footnotetext{
${ }^{1}$ S\&P Capital IQ claims to have it but since we did not have access to their dataset, we could not validate how helpful it is.
} 